\title{
TÄIS- JA OSASIHITISE KASUTAMISEST EESTI KEELT TEISE KEELENA ÕPPIJATE PILGU LÄBI
}

\section{Raili Pool}

Ülevaade. Artiklis antakse lühiülevaade introspektiivsete meetodite võimalustest teise keele omandamise uurimisel. Uurimuse informantideks on vene emakeelega eesti keelt kõrgtasemel valdavad eesti keele (võõrkeelena) eriala üliõpilased. Käsitletakse informantide endi arvamusi ja põhjendusi eesti keele objektikäänete valiku kohta ning seostatakse kogutud materjali nii eesti keele grammatika objektikäsitlusega kui ka eesti keele kui teise keele õpetamisega.*

Võtmesõnad: keeleõpe, teine keel, introspektsioon, objektikäänded, eesti keel

\section{Sissejuhatus}

Teise keele omandamise uurimiseks pakub huvitavaid võimalusi eesti keele kui teise keele puhul veel väga vähe kasutatud introspektiivsete meetodite rakendamine. Niisuguse lähenemisviisi puhul kogutakse empiiriline materjal informantide suulise küsitlemise teel, eeldades, et keeleõppijad suudavad ise jälgida ja kirjeldada mentaalseid protsesse, mis juhivad nende keelelisi tegevusi.

Introspektiivsete meetodite kasutamisvõimalustest teise keele omandamise uurimisel ning nende meetodite liigitusest annavad ülevaate Claus Faerch ja Gabriele Kasper (1987) ning Andrew D. Cohen (1987). A. D. Cohen (1987: 83-84) juhib seejuures tähelepanu asjaolule, et õppijate küsitlemise abil pole siiski võimalik uurida kõiki õppimisstrateegiaid, vaid ainult seda osa, millest küsitletud keeleõppijad ise teadlikud on. Introspektiivsete meetodite abil kogutavad andmed liigitab A. D. Cohen kolme põhikategooriasse (samas: 84-86):

a) aruanne (self-report) - õppijate üldised kirjeldused selle kohta, milliseid õppimisharjumusi endal arvatakse olevat ja milliseks keeleõppijaks ennast peetakse;

b) enesevaatlus (self-observation) - spetsifilise keelelise käitumise vaatlemine, jaguneb omakorda introspektsiooniks ja retrospektsiooniks;

* Artikkel on valminud sihtfinantseeritava teadusteema SF0182568s03 "Eesti-vene, eesti-inglise, eesti-saksa, 
c) self-revelation (sobiv eestikeelne vaste puudub) - õppija aruanne, mis pole ei üldise keelelise käitumise kirjeldus ega põhine ka mingi spetsiifilise keelevaldkonna vaatlusel.

K. Anders Ericsson ja Herbert A. Simon (1987) jagavad enesevaatluse kaheks liigiks vastavalt informantide poolt sooritatava keeleülesande ja selle kommenteerimise vahelisele ajale:

a) samaaegne enesevaatlus - informantidel palutakse ülesande sooritamise ajal n-ö valjusti mõelda, kirjeldades ülesande lahenduseni jõudmise teed;

b) edasilükatud enesevaatlus ehk retrospektsioon - informantidel palutakse kirjeldada ülesande lahendamise käiku kas vahetult pärast selle sooritamist või pikema ajalise distantsiga.

Kokkuvõtlikult võib õppijate endi suuliste aruannete (ingliskeelses kirjanduses nimetatakse seda tüüpi materjali kogumise viise verbal reports) kogumise viisid jagada kolmeks (Seliger, Shohamy 1989: 169-170):

1) valjusti mõtlemine (thinking aloud) - informantidel palutakse ülesande sooritamisega samaaegselt valjusti kirjeldada kõike, mis neil sellega mõttes seostub, ükskõik kui triviaalne see ka ei tunduks;

2) introspektsioon - informandid jälgivad mingi kindla ülesandega liituvaid mõtteid ja arvamusi ning avaldavad need valjusti;

3) retrospektsioon - informatsioon kogutakse informantidelt alles ülesande sooritamise järel, intervjueeritavatelt eeldatakse omaenda mentaalsete protsesside või strateegiate kohta järelduste tegemist.

H. Seliger ja E. Shohamy juhivad eriti just valjusti mõtlemise tehnika rakendamise puhul tähelepanu ka mõningatele probleemidele. Nimelt ei pruugi kahe tegevuse samaaegne sooritamine kõigile vastajatele sobida, mistõttu võib osa vajalikku informatsiooni jääda verbaliseerimata, samuti võivad intervjueeritavad mõnikord väljendada seisukohti, mida nad arvavad küsitlejat ootavat ning mis ei kajasta nende tegelikke mõtteid (samas: 170).

Introspektiivsete meetodite olulisuse võõrkeeleõppes võtab ülevaatlikult kokku Sabine Beyer (2005), kes toob välja 5 valdkonda, milles ülalkirjeldatud meetoditega kogutud andmeid on otstarbekas ära kasutada:

1) ülesannete lahendamise strateegiate kogumine ja liigitamine;

2) õppijakeeles järjekindlalt esinevatele võõrmõjulistele struktuuridele tähelepanu juhtimine ja nende teadvustamine;

3) õppijate metalingvistiliste teadmiste kogumine;

4) testide valideerimine;

5) õppijate individuaalsetele vajadustele orienteerumine keeleõppes.

Siinkirjutaja arvates peaks õppijate enesevaatluse teel kogutud andmete analüüs aitama kaasa ka keeleõppe metoodika arendamisele ning õppematerjalide täiustamisele. Keeleõpetajatel on küll enamasti oma ettekujutus sellest, kuidas nende õpilased keelt õpivad, millistest seaduspärasustest lähtuvad ja kuidas oleks neid kõige otstarbekam õpetada, kuid õppijate endi nägemus oma keelelisi valikuid reguleerivatest mehhanismidest ei pruugi alati õpetajate omaga kokku langeda. Õppijate küsitlemisel saadavad andmed võimaldavad võtta keeleõppes arvesse ka 
õppijate endi soove, hinnanguid ja kogemusi. Eriti täiskasvanud keeleõppijatel võivad juba varem olla välja kujunenud teatud arusaamad või ka õpetajate arvates eksiarvamused sihtkeele kohta, mille nad keeletundi endaga kaasa toovad. Näiteks Eesti kõrgkoolides eesti keelt õppivatel venelastel on varuks pikaajaline eesti keele õppimise kogemus keskkoolist, mille jooksul kinnistunud seisukohad võivad mõju avaldada nende edasistele keeleõpingutele - seda oleks kõrgkooli õppejõududel kasulik õppetööd planeerides taustal hoida.

Eesti keele kui teise keele omandamise uurimine on alles noor valdkond ning introspektiivsete meetoditega kogutud ainestiku analüüsil põhinevaid uurimusi seni veel avaldatud ei ole. Soome keele kui teise keele alal on seevastu kaitstud juba ka mitmeid väitekirju, millest mõnes on käsitletud ka õppijate enesevaatluse teel kogutud ainestikku. Nii on näiteks Maisa Martin (1995: 131-149) oma soome keelt teise keelena kõnelejate vormimoodustust käsitlevas doktoriväitekirjas analüüsinud muu ainestiku hulgas ka õppijate endi kirjeldatud vormimoodustusstrateegiaid ning jõudnud analüüsitud intervjuude põhjal järeldusele, et introspektsioon on tulemuslikum pigem üldiste õpistrateegiate kui spetsiifiliste vormimoodustusstrateegiate uurimiseks, kuna õppijad on rohkem harjunud mõtlema ja rääkima sellest, kuidas nad keelt õpivad, aga mitte nende poolt tegelikult kasutatud produktiivsetest strateegiatest. Kirsti Siitonen (1999) on oma soome keele $u$ verbide omandamise alases väitekirjas kasutanud intervjuusid informantidega, saamaks andmeid nende endi hinnangutest oma $u$-verbide kasutamise oskusele ja kogemusele ning informantide erinevate emakeelte võimalikest seostest soome keele $u$-verbidega. Ühe teise keele õppija probleeme soome keele partitiivi kasutamisel on introspektsiooni teel käsitlenud Eila Hämäläinen (1994), kes toob välja niisuguse uurimismeetodi kahepoolse kasu: küsitletav keeleõppija teadvustab enda keelekasutust, küsitlust läbiviiv õpetaja saab aimu sellest, millist teed pidi tema õpilased sihtkeele kuju saavutamise poole liiguvad.

Käesolev artikkel tutvustab uurimust, milles introspektsiooni on kasutatud ühe kindla grammatikavaldkonna - eesti keele täis- ja osasihitise - kasutamist reguleerivate mehhanismide vaatlemiseks. Uurimuse eesmärgiks on küsitluse teel välja selgitada, kas õppijad on üldse suutelised sellest keerulisest grammatikavaldkonnast rääkima ning kui on, siis kas nad lähtuvad reeglitest või intuitsioonist, millised reeglid nad enda jaoks on selgeks teinud ning milline seos on õppijate endi sõnastatud seaduspärasustel formaalses keeleõpetuses kasutatavate lähenemisviisidega.

\section{Materjal ja informandid}

Informantideks on 15 Tartu ülikooli eesti keele (võõrkeelena) eriala vene emakeelega üliõpilast, kes olid materjali kogumise hetkeks jõudnud oma stuudiumi lõpuossa, olles juba läbinud nii praktilised kui ka teoreetilised eesti keele kursused. Eestis kasutusel oleva tasemeeksamite süsteemi järgi valdasid kõik informandid eesti keelt kõrgtasemel. Uurimuse eelduseks oli, et vaadeldav informandirühm suudab enda keeleliste valikute kirjeldamisel ära kasutada ka oma teoreetilised teadmised sihtkeelest.

Analüüsitav materjal on pärit suulise kõne lindistustest. Iga informandiga on lindistatud sissejuhatavalt 30-40 minutit vaba vestlust sarnastel teemadel (eri- 
alavalik, eesti keele õppimisega seonduv, tulevikuplaanid jm). Seejärel anti informantidele 7 eestikeelset lauset, milles tuli panna sihitis nende arvates sobivasse käändesse ja neil paluti oma valikuid põhjendada, ka informantidepoolne lausete analüüs lindistati. Lindistuse lõpus paluti informantidel avaldada oma arvamust selle kohta, kuidas nende arvates oleks otstarbekas vene emakeelega õppijatele eesti keele objektikasutust õpetada, millised kogetud õpetamisviisid on neid enim aidanud, millest nad ise enamasti täis- ja osasihitise kasutamisel lähtuvad jne. Intervjuud viidi läbi 2004. a kevadel ja sügisel, kõik lindid on litereeritud, nii lindistajaks kui ka litereerijaks oli käesoleva artikli autor. Kuigi introspektsiooni puhul ei mängi rolli see, millises keeles õppijad oma keelelist käitumist kirjeldavad (sageli võetakse appi õppijate emakeel või mõni muu informandile ja küsitlejale ühine keel), toimusid kõik intervjuud eesti keeles, sest vaadeldava informandirühma keeleoskuse tase võimaldas seda.

\section{Sihitise käände valik ja põhjendused}

Järgnevalt tuuakse välja informantidele esitatud 7 lauset koos nende poolt valitud sihitise variantidega ning valiku põhjendustega. Katkendid intervjuudest on esitatud redigeerimata kujul, mistõttu neis võib esineda keelelisi ebatäpsusi, informandid on tähistatud lühenditega INF A, INF B jne, intervjueerija tähiseks on lühend R.P. Iga lause juures tuuakse ära kõik intervjueeritute poolt kasutatud sihitise variandid järjekorras a) nominatiiv, b) genitiiv, c) partitiiv, sulgudes on lisatud iga variandi valinud informantide arv.

(1) Mul on unistus (hispaania keel) ära õppida.

a) Nominatiiv - hispaania keel (2)

Mõlemad nominatiivse täissihitise valinud informandid tuginevad valikul kunagi varem kuuldud lausete analoogiale, õpitud reeglitega oma valikut ei seo. Näiteks:

INF C: sellepärast et mul oli kunagi selline (.) see lause et (...) miski ära kasutada (...) seal oli nagu ära (.) siin on ära ja sellepärast nagu öeldaks niimoodi

b) Genitiiv - hispaania keele (10)

Kõik genitiivi valinud informandid põhjendavad oma valikut ära-adverbi olemasoluga lauses, mis muudab tegevuse lõpetatuks. Siin tuleb selgelt esile sisendkeele mõju ja lähtumine õpitud reeglitest, mille kohaselt kasutatakse lõpetatud tegevuse puhul eesti keeles omastavas käändes täissihitist. Näiteks:

INF I: keele (.) sellepärast et ära õppida (.) see on lõppenud (...) see kohe tahab omastavat

Õpitud reeglitest lähtumise soov ei vii alati sugugi sihtkeelepärase lahenduseni, milleni aga oleks võinud viia intuitsioon või analoogia rakendamine, illustreerimiseks toon välja näite, millise arutluskäigu teel üks informant genitiivobjekti valikuni jõuab.

INF N: esimene mis mul tuli kohe esimest lauset lugedes oli et mul on unistus hispaania keel ära õppida 
R.P.: et nagu nominatiivi jätta (.) mis nagu mõjutab siin

INF N: see on kindlasti nominatiivses (.) mul on unistus hispaania keel ära õppida (.) ma ei teagi

R.P.: mille järgi sa valid (.) kas verb mõjutab või mingisugune muu sõna või mõtled sa vene keele peale siin?

INF N: ei vene keelele kindlasti ma ei mõtle (.) sisemine taju nagu ütleb et see peab olema hispaania keel (.) ma unistan eesti keele ära õppida (.) siis oleks kindlasti omastav (.) mul on unistus hispaania keele ära õppida (.) ei ikkagi vist omastav ka sest ära õppida on (.) ära õppida tähendab et ikkagi kogu keele (.) kogu tähendabki omastavat käänet siis hispaania keele oleks ikkagi

Esitatud näide illustreerib ilmekalt asjaolu, et sihtkeele struktuuri üle pikalt mõtlemine võib ajada kõneleja segadusse ning et esimesena pähe turgatanud spontaanne variant võib osutuda keeleliselt korrektseks. Näitest on näha, et tegelikult viis intervjueerija informandi oma küsimustega eksiteele.

c) Partitiiv - hispaania keelt (2)

Mõlemad osasihitise valinud informandid lähtuvad intuitsioonist, põhjendades, et "nii kuidagi kõlab".

d) Nominatiiv või genitiiv - hispaania keel või hispaania keele (1)

Üks vastaja (INF O) ei tee kindlat valikut, öeldes vaid, et osastava välistab ära, kuid nimetavas ja omastavas kõlab see lause samamoodi, nii et need mõlemad võiksid olla.

INF O: see (.) see esimene lause on jälle selline juhtum (.) mille kohta ma kogu aeg kahtlen (...) kuna see ei saanud selgeks kuidagimoodi (...) siin on see infinitiiv (...) ja siis jälle kui see on lõpetatud tegevus või siis mingi tervik (...) kas see peaks siiski olema nimetav (.) või omastav (...) seda ma mõnikord lihtsalt ei oska öelda (...) ei oska mõelda et mõnikord nii ja mõnikord naa (.) see sõltub sellest ka et kas siin on veel mõni nagu ma olen märganud modaalverb tavaliselt (.) kas võima või tahtma või sellist

R.P.: aga noh loe see lause ja paku kuidas sulle nüüd tundub et kõige parem on

INF O: võib ka mitu varianti (.) see kõlab kas omastavas või nimetavas samamoodi (.) kas mul on unistus hispaania keel ära õppida või hispaania keele ära õppida (...) aga kuidas on õige?

Nominatiivne täissihitis on eesti keeles marginaalne ja kõige suuremate kasutuspiirangutega, selle sihtkeelepärane tarvitamine eeldab teise keele kõnelejatelt põhjalikke teadmisi eesti keele grammatikast, sealhulgas lauseanalüüsi oskust. Viimane on eriti vajalik $d a$-infinitiivi objektide puhul, kuna nominatiivse täissihitise liidab just täiendina (nagu lauses (1) ) ning alusena talitlev $d a$-infinitiiv, sama vorm sihitisena nõuab laiendiks aga ainsuse genitiivis totaalobjekti. Informantide arutluskäikudest on näha, et täissihitisega seostub keeleõppijail esmajoones genitiiv ning et sisendkeelest tuttav perfektiivsusadverb ära on täissihitise kasutamise eelduseks. 
(2) Ühe väikse vea pärast ei pea (terve töö)

a) Nominatiiv või genitiiv - terve töö (1)

Ainuke täissihitise valinud vastaja (INF N) ilmselt ei ole tähele pannud eitavat öeldisverbi, põhjendades käändevalikut tervikliku objektiga:

INF N: terve näitab et kogu töö (.) partitiiviga oleks ainult osa tööst

Kuna nimisõnafraasis terve töö langevad nominatiiv ja genitiiv vormiliselt kokku, ei saa kindlalt väita, kumba täissihitise käänet on informant silmas pidanud. Lähtudes S. Pit Corderi (1981: 5-13) seisukohast keeleõppija vigade ja eksimuste olemusliku erinevuse kohta, tuleks informandi $\mathrm{N}$ valikut kindlasti pidada eksimuseks, kuna käesoleva artikli autori käsutuses olevates materjalides (vaba vestluse litereering ning vabad kirjutised) esinevad sama informandi keelekasutuses eitavates konstruktsioonides ainult sihtkeelepärased partitiivobjektid (suulises kõnes vastavalt 10 ja kirjalikus tekstis 2 eitavat verbi laiendavat osastavalist sihitist).

b) Partitiiv - tervet tööd (14)

Selle lause objektivaliku selgitustes avaldub positiivselt keeleõpetuse mõju, 14 informanti valivad partitiivi põhjendusega, et eitus nõuab partitiivis objekti, vastav reegel (lihtsaim, mis objektikasutust reguleerib) on keeletundides omandatud.

Lause (2) puhul avaldub ka informantide teoreetiliste teadmiste ja nende praktikas rakendamise oskuse ebakõla, nimelt ei osanud mitu informanti tegelikult antud nimisõnafraasist terve töö partitiivivormi moodustada, jättes selle algvormi terve töö (grammatilise homonüümia tõttu võib seda vormi pidada nii nominatiiviks kui ka genitiiviks), kuid teadsid samas, et selles lauses peab olema partitiivne sihitis. Niisugused juhtumid, mille puhul informant on jätnud sulgudes esitatud nimisõnafraasi muutmata, kuid on ise kirjeldanud seda vormi partitiivsena, on arvatud partitiivobjektide hulka. Näiteks:

INF G: ei pea terve töö ümber tegema

R.P.: siin jääb siis?

INF G: terve töö

R.P.: mis küsimus see siis on?

INF G: ei pea mida tegema (.) terve töö ümber tegema (...) osastavas'

Kirjeldatud asjaolu näitab, et pelgalt kirjaliku keelekasutuse analüüsimisel ei saa keeleuurija täie kindlusega otsustada, mida õppijad tegelikult on silmas pidanud, sest viimased võivad oma arust kasutada sihtkeelepärast vormi, mis samas vormiliselt siiski seda ei ole.

(3) Vene emakeelega inimestel on Tartu koolides raske (eesti keele oppetaja koht) .............. leida.

a) Nominatiiv - koht (1)

Nominatiivi valinud vastaja (INF L) põhjendas oma valikut sellega, et verbi $d a$-infinitiivi vorm määrab objektikäände.

b) Genitiiv - koha (8) 
Genitiivi valikut põhjendati:

- verbi enda omadustega (leidma nõuab genitiivi, kuna on tähenduselt lõplik, piiritletud) (4), näiteks:

INF O: leida see on selline verb et see peab olema lõpetatud tegevus (...) see ei ole otsima see on leidma (...) see on kas ma leian või ei leia (.) kas on või ei ole (...) eesti keele õpetaja koha leida minu meelest kohe

R.P.: et ikkagi nagu lõpetatud tegevus ikkagi?

INF O: jah (.) jah

R.P.: et sa otsustad selle verbi järgi?

INF O: jah (.) verbi sisu (.) sisulise nagu poole järgi jah

- objekteseme terviklikkusega (2), näiteks:

INF J: nimetav ei sobi (.) et omastav või osastav

R.P.: mis võiks olla sinu jaoks selleks valikukriteeriumiks?

INF J: kas on terve objekt või osa (...) et terve koha ikka et tervik

R.P.: et kui võtta terve ja osa järgi siis oleks see omastav jah?

INF J: jah omastav

- lõpetatud tegevusega (1)

- vene keele analoogiaga (1), seda illustreerib järgnev näide:

INF C: on raske eesti keele õpetaja koha leida

R.P.: siis mille?

INF C: jah

R.P.: mis asi on siin lauses mille järgi sa seda käänet valid või panid lihtsalt intuitsiooni järgi?

INF C: ei (...) lihtsalt küsisin oma peas (...) ai (...) see on vene keeles совершенный vхі несовершенный вид

R.P.: ahaa (...) nii et sa mõtlesid praegu nagu peas vene keele peale

INF C: mhmh

R.P.: kuidas see vene keele järgi oleks siin siis?

INF C: что сделать

R.P.: nagu совершенный вид?

INF C: jah (...) koolis oli meil üks valem

R.P.: no kirjelda mis valem see oli

INF C: pean kirjutama

R.P.: no kirjuta (...) kas see oligi nagu seotud vene keelega või?

INF C: mõlema keelega (...) nii совершенный on $C$ aga несовершенный $H$ ja kui on совершенный siis läheb omastav kui несовершенный siis osastav (...) kirjutan siia HOC ja kui on совершенный siis $C O M$ siis läheb omastav aga kui несовершенный siis HOC osastav 
R.P: kas sa oled seda valemit kasutanud (.) kas see aitab sind?

INF C: $\mathrm{mhmh}$

R.P.: nii et selles kolmandas lauses sa mõtlesid selle $\tilde{N} \hat{I} I \overline{-i}$ peale?

INF C: mhmh

c) Partitiiv - kohta (6)

Põhjendused:

- lõpetamata tegevus, ei ole teada, mis saab (1)

- $\quad$ konstruktsioon on raske nõuab enda järel osastavat (1)

- $\quad$ sisemise taju järgi (2), näiteks:

INF N: muidugi kui ma esitan selle küsimuse et mida on raske leida (...) siis oleks osastav (.) eesti keele õpetaja kohta leida (.) ei ma ikkagi kaldun osastava käände

R.P.: et ikkagi mida leida

INF N: jaa mida leida jah (.) on Tartu koolides raske eesti keele õpetaja kohta leida

R.P.: mhmh (.) et lihtsalt mingi sisemine taju ütleb?

INF N: jah

R.P.: et sulle tundub et eestlased räägiksid nii?

INF N: kui ma nii otsekohe pean ütlema siis jah

R.P.: esimene vastus on tavaliselt õige (.) või mõte mis pähe tuleb

INF N: noh (.) kui tavakeeles ma peaksin seda ütlema (.) siis võib-olla ma ei mõtlekski sellele

- $\quad$ ei põhjenda üldse (2)

Selle näitelause valiku taustaks on artikli autori poolt praktilise eesti keele õpetamisel üliõpilaste kirjalikes töödes sageli kohatud laused, milles konstruktsioonis on raske $+d a$-infinitiiv on tarvitatud nominatiivset või genitiivset objekti, infinitiivina esineb neis kõige sagedamini verb leida. Introspektiivsed andmed kinnitasid filoloogiaüliõpilastest informantide suundumust tarvitada niisugustel juhtudel täissihitist, kuna verb leidma on sisult resultatiivne. Eesti keele reeglite kohaselt oleks $d a$-infinitiivse subjekti laiendina küll võimalik ainult nominatiivne täissihitis, teise keele kõnelejatele on $d a$-infinitiivi laiendav objekt aga väga keeruline ja detailsete reeglite ning lauseliikmete tundmist eeldav teema, mistõttu genitiivse täissihitise valik oli täiesti ootuspärane. Samas on tegemist konstruktsiooniga, milles emakeelekõnelejad ise täissihitist (seega nominatiivivormi) peaaegu üldse ei kasutaks. Et mitte lähtuda seesuguse väite puhul ainult iseenda kui emakeelekõneleja keeletajust, toon näite nii teise keele kõnelejate kui ka emakeelekõnelejate seas läbi viidud pikemast objektitestist. ${ }^{1}$ Testis esinenud lauses Väikeste palkade tõttu on direktoril raske koolile .......... leida, milles lünka tuli valida sobiv kolmest valikvariandist: A uus inglise keele õpetaja, B uue inglise keele õpetaja, C uut inglise keele õpetajat, valisid 30 vastajast (eesti keelt emakeelena kõnelevad üliõpilased) 27 variandi $\mathrm{C}$ ehk osasihitise ning ainult kolm variandi A ehk nominatiivse täissihitise (ka need kolm lisasid sulgudes veel

${ }^{1}$ Nimetatud testi on läbi viinud artikli autor eesti keele sihitise kasutuse edasise uurimise eesmärgil, selles artiklis testi andmetel pikemalt ei peatuta. 
variandi C kui teisena võimaliku). Kuigi sihitise kasutamise reeglid seesugustes lausetes nominatiivobjekti tarvitamist otseselt ei keela, on sihtkeelepärase keelekasutuse poole pürgivatele teise keele kõnelejatele mõttekas õpetada konstruktsioone on raske / on kerge $+d a$-infinitiiv seesugustena, kus partitiivobjekti kasutamine on kindlam. Niisuguse objektikasutuse taustaks on ilmselt juba "Eesti keele lauseõpetuse põhijoontes" (Mihkla jt 1974: 162) esitatud ning "Eesti keele grammatika" süntaksiosas (EKG II 1993: 248) korratud asjaolu, et da-infinitiivi objekti vorm ei olene infinitiivist endast, kui infinitiiv laiendab tundmust väljendavaid verbe armastama, häbenema, kartma jt, vaid nende verbide puhul on dainfinitiivi objekt alati partitiivis. Kuigi siinkirjutaja ei nõustu täielikult eelnimetatud grammatikates väidetud partitiivobjekti ainuvõimalikkusega nimetatud verbiühendites, on siiski võimalik tuua paralleele ühendite on raske / on kerge ja nn tundmust väljendavate verbide vahel, mis mõjutavad sihitisekasutust, nõrgendades verbi leidma resultatiivset tähendust. Ühendi on raske $+d a$-infinitiiv eitavat sisu pole põhjust partsiaalobjekti eelistamise kriteeriumiks pidada, kuna jaatava sisuga ühend on kerge + da-infinitiiv käitub objektikäände valiku suhtes sarnaselt, pigem võib mõjutada seesuguste konstruktsioonidega väljendatud tegevuste tajumine protsessina.

\section{(4) Laeva väljumiseni on vähe aega, nii et me võtame bussijaamast (takso) .................. ja sõidame sadamasse.}

a) Nominatiiv - takso (1)

INF H: kui oleks see, siis mille, see oleks nagu rohkem määratud, aga takso siis mis

b) Genitiiv - takso (10), valiku põhjendused olid järgmised:

- lõpetatud tegevus (ja piiritletud objekt) (5), näiteks:

INF D: võtame bussijaamast takso

R.P.: mis käändes see takso siin on?

INF D: genitiivis

R:P.: mhmh (.) ja mille järgi sa valiksid selle käände?

INF D: võtame mille (.) lõpetatud tegevus (.) piiritletud objekt

- terviklik objekt (4), näiteks:

INF J: takso (.) see on omastav (...) siin on rohkem tulevikus ja kuna see on tulevikus siis takso on omastavas (...) ja veel takso on terve objekt

- ei põhjenda (1)

c) Partitiiv - taksot (4), igal informandil oli oma nägemus:

INF A: mõtlen ajahetkele, see on hetkel

INF C: valem HOC - несовершенный вид + osastav

INF G: võtame mida, mudel on välja kujunenud

INF L: võtame mida, ei oska täpselt seletada, aga vene keel ei mõjuta

Lause (4) objektnoomeniks oli valitud nominatiivis ja genitiivis kokkulangevate vormidega takso, et introspektsiooni abil välja selgitada, millist käänet täissihitise valinud informandid tegelikult silmas peavad. Eesti keele grammatilise homo- 
nüümia tõttu pole alati selge, missugust kahest või mõnikord ka kolmest vormiliselt kokkulangevast objektikäändest teise keele kõnelejad tegelikult on mõelnud. Eesti keelt emakeelena kõnelejate keelekasutust analüüsides võiks uurija tugineda iseenese kui samuti emakeelekõneleja keeletajule, teise keele kõnelejate puhul ei pruugi niisugune lähenemisviis anda tõeseid vastuseid, sest keeleõppijate valikud on sageli prognoosimatud.

Vastustest selgus, et vaadeldav informandirühm on omandanud reegli, mille kohaselt isikulise tegumoe kindlas kõneviisis pöördelise verbivormi laiendina ainsuse nimetavas käändes sihitist ei kasutata, ${ }^{2} \mathrm{ka}$ ainsana nominatiivi valinud informandi $\mathrm{H}$ valikut võib tema muu keelekasutuse taustal pidada juhuslikuks. Käsitletav keelematerjal ei kinnita üldlevinud arvamust, mille kohaselt vene emakeelega õppijad kalduvad liigtarvitama partitiivobjekti (Ehala 2000: 30), mis on eesti keeles markeerimata objektikääne ning mille vene emakeelega õppijad valivad sageli vene akusatiivi eesti vasteks. Neljal osasihitise valinud informandil on igaühel erinev põhjendus, huvitav on sealjuures jälgida paralleelide toomist vastajate emakeelega. INF C, kes toetub sihitise kasutamisel peaaegu alati emakeelele, toob ka selle lause puhul kriteeriumina välja seose vene aspekti ja eesti objektikäände vahel, valides kummatigi lause (4) venekeelses vastes esineva perfektiivse aspekti (vrd возьмем такси - совершенный вид) asemel imperfektiivse, mitte arvestades aspektuaalsuse seisukohast olulist lause esimest poolt, valides kokkuvõtteks eesti keeles mittesihtkeelepärase vormi. Samas peab INF L vajalikuks eraldi rõhutada, et kuigi ta kasutaks antud lauses partitiivi, ei ole see vene keele mõju. Niisugused küsitlusandmed näitavad, et isegi kui emakeele mõju on teise keele õppijate keelevigade põhjusena tõenäoline, võivad (eriti kõrgtasemel kõnelejate puhul) tegelikkuses olla vea taustaks hoopis mingid muud tegurid.

\section{(5) Istusin eile ôhtul kodus ja kuulasin (uus plaat)}

a) Partitiiv - uut plaati (15)

- kuulama on partitiivverb (7), näiteks:

INF N: verb nõuab partitiivi, kui terve plaadi, siis peaks lisama läbi

- kestev, lõpetamata tegevus (7), näiteks:

INF H: see on lihtsalt nagu protsess (.) et kui kuulasin ära siis peab ära panema

Järgmine näide illustreerib asjaolu, et alati ei pruugi olla korrektne esimesena pähe turgatanud võimalus, vaid et sihtkeelepärase variandini võib jõuda ka pikema arutluskäigu tulemusena:

INF M: istusime eile õhtul kodus ja kuulasime uue plaadi (...) siin on minevik (.) minevikus on (...) kuulasime (...) siin võib olla ka teine variant ma arvan osastavas sest siin on selline (.) mitte lõpetatud tegevus aga (.) kestev (.) kestev tegevus (.) mingi aja jooksul kuulasime uut plaati (.) siis osastavas

R.P.: et osastavas parem oleks? või mõlemad variandid? sa pakud et võib nii omastav kui osastav vastavalt situatsioonile?

INF M: ma arvan et osastav siin on parem (.) et siis teatud periood on mõeldud 
- $\quad$ intuitsiooni järgi (1)

INF G: kuulasin mida (.) uue plaati (...) kui kuulasin mida (.) ikkagi tuleb uut plaati (...) osastav peaks olema

R.P.: kas selle verbi pärast või mis siin nõuab osastavat või jälle intuitsioon või?

INF G: intuitsioon jah (...) halb õpilane (.) ei oska seletada

Lausesse (5) oli öeldiseks valitud partitiivverbide hulka kuuluv kuulama (partitiivverbidest vt EKG II: 49-51), selgitamaks välja, kas keeleõppijad peavad eesti keele transitiivsete verbide liigitamist kolmekäändelist sihitist võimaldavateks aspektverbideks ja ainult partitiivset sihitist liitvateks partitiivverbideks objektikäände valikul arvestatavaks kriteeriumiks või on see ebaoluline. Kuna tegemist on levinud verbiga, ei ole sajaprotsendilises õigete vastuste hulgas midagi üllatavat. Küsitlusandmed toetavad õppematerjalides levinud lähenemisviisi, mille kohaselt partitiivverbid tuleks meelde jätta ja nende puhul täiendavatele objektikasutuse tingimustele mõtlema ei pea.

(6) Tüdruk kasvatas oma (juuksed) pikaks.

a) Nominatiiv - juuksed (14), põhjendused võib jagada gruppideks:

- lõpetatud tegevus, lõpetatust näitab pikaks (6), näiteks:

INF E: tüdruk kasvatas oma juuksed pikaks (.) nimetav ja mitmus (.) juuksed ongi juba mitmuses ja

R.P.: miks just see nimetav jääb miks juukseid ei jää?

INF E: no see on kuidagi konkreetne lause selles mõttes et on konkreetne tüdruk ja temal on konkreetsed juuksed (.) mitte lihtsalt mõningaid juukseid kellelgi (.) et oma juuksed ja (...) ja see pikaks ka näitab veidi seda lõpetatust et (.) ta otsustas mille- millenigi jõuda

- määrav on verbi minevikuvorm (2), näiteks:

INF J: siin on jälle raske (...) kasvatas oma juukseid pikaks või oma juuksed pikaks (.) kas kõik juuksed või osa

R.P.: et sa lähtud sellest objektsõnast endast?

INF J: aga äkki see kasvatas-verb nõuab osastavat? (...) näiteks kasvatas loomi (.) võib-olla siin on hoopis osastav?

R.P.: mis siin lauses võiks veel mõjutada?'

INF J: pikaks (...) et nad ei ole veel pikad (...) et need on protsessis

R.P.: ja kui on protsess siis võiks sobida partitiiv jah

INF J: jah (.) ja kasvatas on minevikus (...) et ikka lõpetatud

R.P.: nonii

INF J: kui on lõpetatud siis on juuksed

R.P.: siis on juuksed

INF J: nimetav

R:P.: nii et sinu lõplik otsus oleks ikkagi et kasvatas juuksed pikaks?

INF J: jaa 
- $\quad$ terviku tähendus (2)

- intuitsiooni järgi (4), näiteks:

INF D: juuksed on nominatiiv (...) ei saa olla partitiivis

R.P.: kas objektnoomen ise või verb või lause tähendus?

INF D: kasvatas pikaks (...) ma ei oska seletada (.) ma olen kindel et siin on nominatiiv

b) Partitiiv - juukseid (1)

Ainuke osasihitise valinud informant lähtub objektikäände valikul ilmselt intuitsioonist, andmata täpsemaid põhjendusi.

INF G: tüdruk kasvatas oma juukseid pikaks

R.P.: mida?

INF G: mida jah (.) osastavas mitmuses

R.P.: miks sa nii arvad?

INF G: kasvatas mida (...) ei oska seletada

Lauses (6) sisalduva öeldisverbi kasvatama valiku taustaks on asjaolu, et eesti keele partitiivverbid jagunevad omakorda veel kaheks: ainult partitiivobjekti liitvateks (nt austama, vihkama jt) ning resultatiivsete laiendite olemasolul ka täissihitist võimaldavateks (nt veeretama, loopima jt). Partitiivverbide kahesugust käitumist objekti vormivõimaluste suhtes on Huno Rätsep (1978) arvestanud oma verbikesksete lausemallide kirjeldamisel, Birute Klaas (1999) on oma käsitluses nimetanud esimest tüüpi verbe tugevateks ning teisi vastavalt nõrkadeks partitiivverbideks. ${ }^{3}$ Lauses (6) kasutatud kasvatama sarnaneb liigituse kohaselt nn nõrkade partitiivverbidega, liites ilma resultatiivsete laienditeta sageli vaid osasihitise (nt kasvatan last - keda?), ${ }^{4}$ milline kasutusviis tuli esile ka INF J pikemas arutluskäigus ning mis ilmselt on ka ainukese partitiivobjekti valinud vastaja (INF G) intuitiivse valiku taustaks. Samas on esitatud näitelausesse lisatud resultatiivne laiend pikaks, mis koos täissihitisega muudab lause tervikuna perfektiivseks (partitiivobjekti kasutamine selles lauses võimaldab tegevust mõistagi ka kestvana tõlgendada). Autori eesmärgiks oli välja selgitada, kas nimetatud laiendi olemasolu lauses võib olla informantide jaoks täissihitise valiku kriteeriumiks. Introspektiivsed andmed näitavad, et nn nõrkade partitiivverbide kahesugust käitumist objekti liitmise seisukohast, eriti nende täissihitise liitmise võimalustest resultatiivsetes konstruktsioonides tasuks eesti keele kui teise keele õpetamisel senisest rohkem käsitleda.

(7) (Kõrgharidusega inimesed) hinnatakse tööturul kõrgelt.

a) Nominatiiv - kõrgharidusega inimesed (3)

- otsustav on umbisikuline tegumood (2), näiteks:

INF A: kõrgharidusega inimesed hinnatakse (...) siin on umbisikuline

- $\quad$ toetumine emakeelele (1)

INF C: COM-valem - совершенный вид + omastav, aga et siin on mitmus, siis nimetav 5 
b) Partitiiv - kõrgharidusega inimesi (12)

- hindama nõuab partitiivi (10), näiteks:

INF F: osastav sest (...) no ma arvan et see on partitiivne verb mis nõuab osastavat (.) aga vot siin nendel juhtudel ma mõnikord nagu ei tea (...) see umbisikuline tegumood kas kasutada nimetavat või osastavat (.) aga siin ma arvan ikka osastav

- umbisikuline tegumood, ebamäärane hulk inimesi (1)

INF E: kõigepealt siin on umbisikuline tegumood ja siis (.) kuna ei öeldud kui palju neid inimesi on (.) ei ole teada kui palju täpselt neid on siis osastav (...) omastav siin üldse ei saa olla (.) et siis kas või nimetav mitmus või siis osastav mitmus ja ongi osastav sest ei ole teada kui palju neid on (.) ebamäärane hulk jah

- intuitsioon (1)

INF I: siin on hinnatakse inimesi (...) aga kuidagi kokku viia neid ei suuda

R.P.: sa ütlesid ma ei kuulnud hästi inimesed või inimesi?

INF I: inimesi (...) aga põhjendada ma isegi ei oska

R.P.: et lihtsalt tundub

INF I: tundub jah (...) no ma ei ütleks et kõrgharidusega inimesed hinnatakse (.) see oleks täitsa vale minu arust

Lause (7) võimaldab jälgida informantide seisukohti impersonaalse öeldisverbiga liituva objekti kohta. Vastused näitavad, et vaadeldava informandirühma jaoks on impersonaalsusest määravam öeldisverbi kuulumine partitiivverbide hulka. Niisuguste tulemuste taustaks võib olla see, et vastajad on filoloogiaüliõpilased, kes on sisendkeelest saanud lähtepositsiooni, mille kohaselt partitiivverbide puhul pole täiendavatele objektikäänet mõjutavatele tingimustele tarvis mõelda.

\section{Üldisi arvamusi täis- ja osasihitise kasutamisest}

Lindistuse lõpuks palusin informantidel vabas vormis kirjeldada, millest nad tavaliselt sihitise käänete valikul lähtuvad, millele nad lauseid moodustades või harjutusi tehes tuginevad, mis neid on objektikasutuse õppimisel aidanud. Eraldi küsisin, kas informantide arvates tuleks venelastele eesti keele sihitist õpetades ka vene keelega paralleele tuua ja kas nad ise arvavad, et emakeel neid objektikasutusel mõjutab või mitte.

15 informandist ühe vastused ei olnud kahjuks lindilt tehnilistel põhjustel kuulda, seega kajastavad järgnevalt esitatavad seisukohad 14 informandi arvamusi. Neist üks (INF G) tunnistas, et tema jaoks on sihitise kasutamine ikka veel arusaamatu ning mingeid seaduspärasusi ta enda jaoks selgeks saanud ei ole.

R.P.: mis see sinu põhikriteerium on?

INF G: kui hakkan mõtlema siis ikka verbist sõltub mis küsimust ma esitan

R:P.: kuidas sa verbi juurde valid seda käänet (.) et kas sa mäletad et oled oppinud et on osa verbe mis tahavad alati partitiivi? 
INF G: ei mäleta (...) ei tee vahet (.) niimoodi selgelt ei ole õpitud et neid ma kasutan nagu omastavaga ja neid jälle osastavaga ja (...) ei tea tegelikult

R:P.: et sul on ikka nagu mingi verbi juurde meelde jäänud et siin võiks olla see või see aga ei vaata tervet lauset

INF G: ei vaata tervet lauset (...) see ongi minu viga vist

R.P.: on ju veel see et kas lause tegevus jõuab lõpule või

INF G: seda ma ei saa aru kas tegevus on lõpetatud või lõpetamata (...) ma tean et sellest nagu tulevadki minu probleemid omastava ja osastavaga (...) et ma ei tunne mul see keeletaju ei ole (.) vist välja arenenud

Vene keelele toetumist kinnitasid eesti keele objektikasutuse puhul 3 informanti, ülejäänud väitsid, et vene keele perfektiivse ja imperfektiivse aspektiga (vn совершенный/несовершенный вид) nad üldse paralleele ei too. Üks informant tõdes end tundvat, et vene keel mõjutab tema eesti keele sõnajärge, aga kindlasti mitte objektikasutust. Ka emakeele võimalikku kaasamisse venelastele eesti keele sihitise õpetamisel suhtusid informandid vastandlikult. Üks vastaja (INF F), kes ise juba vene koolis veidi eesti keelt on õpetanud, arvas, et vähemalt algtasemel oleks vene emakeelega õppijatel siiski vene keelega võrdlemisest abi, teine (INF D) leidis aga vastupidist, et vene keelega võrdlemisest ei oleks eriti palju kasu ning tuleks tähelepanu pöörata just eesti keele iseärasustele.

Peaaegu kõik informandid leidsid, et eesti keele transitiivsete verbide liigitus partitiivverbideks ja aspektverbideks on vajalik ja aitab keeleõppijat, sagedasemad partitiivverbid jäävad meelde, aga probleemiks on just see, et õppijad ei tea iga kord, kas tegemist on partitiivverbiga või mitte. Ainult üks vastaja (INF I) ütles, et partitiivverbid ei ole tema jaoks mingiks kriteeriumiks, et ta ei teagi neid. Mitmel juhul öeldi, et sagedasemate partitiivverbide puhul on objektikasutus juba automaatne.

6 informanti kinnitasid, et nad on eestikeelses tekstis nii mõnigi kord terve lause just objekti tõttu ümber teinud, ehk teisisõnu rakendanud ebakindluse korral keeleõppijate seas levinud vältimisstrateegiat. Näiteks:

INF L: kui kirjutan kirjandis näiteks ja ei oska valida kas omastav või osastav (.) siis lihtsalt võtan teise lause

Vältimisstrateegiatest räägiti mõnikord juba lausete analüüsi juures. Näiteks INF N ja küsitleja vahel arenes lause (3) puhul järgmine mõttevahetus:

INF N: mina oleks vist kindlasti kuidagi teisiti sedasama öelnud

R.P.: nii et kui sa ei ole kindel endas sa valiksid teise konstruktsiooni?

INF N: jaa (.) tegelikult ma ette ei mõtle kuidas ma seda ütlen aga

R.P.: aga kirjalikus tekstis?

INF N: jah (.) kirjalikus tekstis kindlasti (.) kui ma loen lauset ja tunnen et siin ma kahtlen (.) siis ma kirjutan ümber

R.P.: kas on sul olnud ka selline olukord mõnikord et sa just selle objekti selle sihitise pärast hakkad kahtlema

INF N: kindlasti kindlasti (.) see ei ole mõnikord see on päris tavaline asi 
Käesoleva uurimuse informantidelt kogutud introspektiivse materjali põhjal leidis kinnitust tavaarusaamana levinud seisukoht, mille kohaselt levib keeleõppijate seas teadmine, nagu tuleks umbisikulises tegumoes öeldisverbi laiendina kasutada kindlasti nominatiivset objekti ning just seetõttu kahtlesid mitmed vastajad ka lauses (7) sobiliku sihitisekäände valikul. Näiteks vastuseks küsimusele, kust selline arusaam pärit on, annab INF F keeleteadusliku põhjenduse, mis kummatigi näitab, et deklaratiivsed metalingvistilised teadmised ei toeta alati produktiivset keelekasutust:

INF F: jah (.) mind õpetati (.) eesti keele käsiraamatus on ka öeldud et kui alust ei ole siis objekt on nagu nominatiivis (.) nagu asendab seda alust (...) aga peab vaatama ka kas on partitiiviverb

Küsimusele, millest intervjueeritavad täis- ja osasihitise kasutamisel kõigepealt lähtuvad, vastati erinevalt, toon välja mõned konkreetsed vastused.

INF D: kui ei ole $d a$-infinitiivi, umbisikulist tegumoodi, siis ma mõtlen kas tegevus on lõpetatud või lõpetamata, kas objekt on piiritletud või piiritlemata

INF B: kõigepealt vaatan verbi, et kas on lõpetatud tegevus, sellised verbid nagu andma, võtma ja leidma nõuavad ikka genitiivi

INF N: peamiselt mõtlen osale ja tervikule, ka lõpetatusele ja lõpetamatusele Illustreerimaks küsitleja ja informantide vahelisi jutuajamisi, olgu järgnevalt esitatud ka üks pikem vestluslõik.

R.P.: kas sul on endal mingi sisemine süsteem kui sa neid sihitise käändeid pead kasutama või sa lähtud lihtsalt intuitsioonist?

INF E: no intuitsioonist küll aga teadmistest samuti (.) et näiteks mõnikord ma arvan üsna valesti (...)

R.P.: aga mis on need põhiasjad mis aitavad?

INF E: no kõige esimesed asjad mis ma inimestele ka ütlen kui ma seda seletan et eitus ja -takse, -dakse (.) siin on hästi kerge öelda et umbisikuline tegumood siin omastavat ei võigi olla

R.P.: omastavat ei või jah aga kuidas valida nimetava ja osastava vahel?

INF E: vot see on juba raske (...) see on juba määratud või ebamääratud hulk et (.) selle kohta saab vähemalt seda osastavat otsustada kas

R.P.: kas nagu oluline on sinu jaoks see verb mille juurde sihitis kuulub või kogu lause?

INF E: no kõigepealt vaatan verbile ikka (.) et mis tegevus on ja siis võibolla arv (.) noh verb selle all ma mõtlen ka eitust (...) siis arv ja no üldse mida lause tähendab ja mida sellega öelda tahetakse

R.P.: kas see aitaks venelasi kui me liigitame neid verbe et on osa selliseid mis tahavad alati partitiivi?

INF E: seda küll jah (.) ma nendest unustasin veidi (.) et kui tead et sellega kindlasti tuleb osastav siis jah (.) a ma mõtlesin nende hulgast et (...) seda 
mida ma tean et näiteks räägime eesti keelt (.) et siin on osastav kindlasti et rääkima tegusõnaga alati seda kasutatakse (...) ja kui ma kellelegi seletan ka et selline tegusõna ja ainult selline kääne sellega et pane tähele ja ongi kõik

\section{Kokkuvõtteks}

Artiklis käsitletud empiiriline materjal tõendas, et vaadeldav üliõpilasrühm oskab eesti keele sihitise kasutuse seletamisel oma lingvistilisi teadmisi väga hästi rakendada. Introspektiivsete meetodite kaasamine filoloogiaüliõpilastest informantidelt andmete kogumiseks õigustab ennast ning võimaldab hankida teavet, mida saab ära kasutada nii õppematerjalide koostamisel kui ka õppetöö planeerimisel. Küsitlus näitas, et eesti keele kui teise keele õpetuses tasub hoida taustal transitiivsete verbide liigitust partitiivverbideks ja aspektverbideks, informantide kinnitusel on sellisest eristusest abi. Sihitise käänete õpetamisel tuleks rõhutada asjaolu, et eesti keeles ei ole konstruktsioone, mis nõuaksid vältimatult ainult nominatiivset sihitist, nagu on üldistunud mitmete õppijate teadmistes impersonaal ja imperatiiv, vaid et ka nendel juhtudel tarvitatakse öeldisverbist ning terviklausest sõltuvalt sageli partitiivset objekti. Selgeks tuleb õppida/õpetada need kontekstid, millal partitiivobjekti paariliseks on genitiivne ja millal nominatiivne täissihitis, eriti vajab harjutusmaterjali nominatiivse täissihitise kasutus. Filoloogiaüliõpilaste jaoks õppematerjale tehes on võimalik rääkida ka lauseliikmetest, eriti oluline on see $d a$-infinitiivi laiendava objekti puhul. Materjal näitas, et õppijate arvates allub $d a$-infinitiivi objekt sageli samadele reeglitele, samas kui alusena ja täiendina talitlev $d a$-infinitiiv ja sihitise funktsioonis olev $d a$-infinitiiv liidavad endaga erinevas käändes ainsusliku täissihitise.

Introspektsiooni teel saadavaid andmeid on võimalik kasutada ka veaanalüüsi puhul, võimaldades vigade seletamise etapil arvesse võtta keeleõppijate endi põhjendusi oma keeleliste valikute kohta. Artikli materjalist selgus, et kohtades, kus kontrastiivse analüüsi järgi tuleks vea põhjusena käsitada emakeele mõju, näitavad informantide enesevaatluse teel saadud andmed ka muid tegureid, emakeele rolli keelevigade põhjustajana ei tohiks niisiis üle tähtsustada.

Kirjeldatud informandirühma tervikuna iseloomustab soov lähtuda reeglitest, mis aga objektikäänete kasutamisel ei vii paraku alati soovitud tulemuseni, seda eriti täissihitise puhul; analoogia rakendamine, intuitsioonile toetumine ning emakeelega paralleelide tõmbamine iseloomustab vaid üksikuid informante.

\section{Kirjandus}

Beyer, Sabine 2005. Introspektive Verfahren im fremdsprachlichen Unterricht. - Deutsch als Fremdsprache. Zeitschrift zur Theorie und Praxis des Deutschunterrichts für Ausländer. 1. Quartal, Heft 1-42. Jahrgang, 18-22.

Cohen, Andrew D. 1987. Using verbal reports in research on language learning. - Introspection in Second Language Research. Ed. by Claus Færch, Gabriele Kasper. Clevedon, Philadelphia: Multilingual Matters, 82-95.

Corder, S. Pit 1981. The significance of learner's errors. - Error Analysis and Interlanguage. Oxford: Oxford University Press, 5-13. [Reprinted from International Review of Applied Linguistics 1967, Vol. 5, No. 4, 161-170.] 
Ehala, Martin 2000. Second language learners' impact on the structure of Estonian. Languages at Universities Today and Tomorrow. Ed. by Kiira Allikmets. Tartu, 2032.

EKG II = Erelt, Mati; Kasik, Reet; Metslang, Helle; Rajandi, Henno; Ross, Kristiina; Saari, Henn; Tael, Kaja; Vare, Silvi 1993. Eesti keele grammatika. II. Süntaks. Lisa: Kiri. Eesti Teaduste Akadeemia Keele ja Kirjanduse Instituut. Tallinn.

Ericsson, Anders K.; Simon, Herbert A. 1987. Verbal reports on thinking. - Introspection in Second Language Research. Ed. by Claus Færch, Gabriele Kasper. Clevedon, Philadelphia: Multilingual Matters, 24-53.

Færch, Claus; Kasper, Gabriele 1987. From product to process - introspective methods in second language research. - Introspection in Second Language Research. Ed. by Claus Færch, Gabriele Kasper. Clevedon, Philadelphia: Multilingual Matters, 5-23.

Hämäläinen, Eila 1994. Partitiivia pitkin ja poikin - suomenoppijan partitiiviongelmia. Suuntaa suomenopetukseen - tuntumaa tutkimukseen. Toim Minna Suni, Eija Aalto. Jyväskylä: Jyväskylän yliopisto, Korkeakoulujen kielikeskus, 23-36.

Klaas, Birute 1999. Dependence of the object case on the semantics of the verb in Estonian, Finnish, and Lithuanian. - Estonian: Typological Studies III. Ed. by Mati Erelt. Tartu, 47-83.

Martin, Maisa 1995. The Map and the Rope. Finnish Nominal Inflection as a Learning Target. University of Jyväskylä. Jyväskylä.

Mihkla, Karl; Rannut, Lehte; Riikoja, Elli; Admann, Aino 1974. Eesti keele lauseõpetuse põhijooned I. Lihtlause. Tallinn: Valgus.

Pastuhhova, Olga 2005. Interferentsivead vene üliõpilaste suulise ja kirjaliku eesti keele süntaksis. - Teine keel. Uurimusi eesti keele kui teise keele omandamisest. Toim Raili Pool. Tartu Ülikooli eesti keele (võõrkeelena) õppetooli toimetised 5. Tartu: Tartu Ülikooli Kirjastus, 75-110.

Pool, Raili 2005. Täis- ja osasihitis kõrgtasemel eesti keelt teise keelena kõnelejate kirjalikus keelekasutuses. - Teine keel. Uurimusi eesti keele kui teise keele omandamisest. Toim Raili Pool. Tartu Ülikooli eesti keele (võõrkeelena) õppetooli toimetised 5. Tartu: Tartu Ülikooli Kirjastus, 8-74.

Rätsep, Huno 1978. Eesti keele lihtlausete tüübid. Tallinn: Valgus.

Seliger, Herbert W.; Shohamy, Elana 1989. Second Language Research Methods. Oxford University Press.

Siitonen, Kirsti 1999. Agenttia etsimässä. $u$-verbijohdokset edistyneen suomenoppijan ongelmana. Väitöskirja. Turun yliopiston suomalaisen ja yleisen kielitieteen laitoksen julkaisuja 63. Turku.

Vaiss, Natalia 2004. Eesti keele aspekti väljendusvõimalusi vene keele taustal. Magistritöö Tallinna ülikooli eesti filoloogia osakonnas. 


\section{ON THE USE OF TOTAL AND PARTIAL OBJECT THROUGH THE EYES OF THE LEARNERS OF ESTONIAN AS A SECOND LANGUAGE}

\section{Raili Pool}

The informants of the study were 15 native Russian speakers who are students of Estonian as a foreign language and who speak Estonian fluently. The data originates from oral recordings, during which 7 sentences in Estonian were presented to the students, who were asked to use the appropriate object case (Nominative, Genitive or Partitive). They were also asked to explain the reasons of their choice. The choices and opinions of the subjects will be connected to the object usage of the Estonian grammar and the problems of teaching.

Analysis of the empirical data shows that the informants who are linguistics students are able to exploit their knowledge when commenting their use of object cases. By questioning the students, it is therefore possible to obtain helpful information with which to compile teaching materials and plan tutoring. The questioning indicates that in the teaching of Estonian object cases, it is useful to consider the fact that Estonian transitive verbs are classified as partial and aspect verbs. When teaching Estonian it is important to emphasize that Estonian language doesn't have constructs which invariably demand nominative objects (as objects of impersonal and imperative verbs are fixed in the knowledge of some language learners) but it is always possible to construct the use of the partitive object.

In general, the subjects are characterized by a wish to follow the rules; apply of analogy, rely on intuition and draw parallels with L1 characterizes only individual subjects.

Keywords: language learning, second language, introspection, object cases, Estonian language

Raili Pool (1969) on lõpetanud Tartu Ülikooli eesti filoloogia erialal 1992. a, samast aastast töötab Tartu Ülikooli eesti keele (võõrkeelena) õppetoolis. Kaitses magistrikraadi Tartu Ülikoolis 1999. a eesti keele alal. Peamiseks uurimisvaldkonnaks on eesti keele kui teise keele omandamine ja kasutus. raili.pool@ut.ee 